\title{
Asymmetric post-announcement drift to good and bad news: Evidence from voluntary trading disclosures in the Chinese stock market
}

\author{
XiaoHua Chen ${ }^{\mathrm{a}}$, Edna Solomon ${ }^{\mathrm{b}} \&$ Thanos Verousis $^{\mathrm{c}}$
}

\begin{abstract}
This paper investigates the post-announcement drift (PAD) of stock returns in the Chinese stock market. We use a sample of voluntary trading disclosures to test the hypothesis that an asymmetric PAD exists in a market in which managers are more likely to suppress negative news. We show that a pattern of short-term momentum and long-term reversal in returns persists for up to 250 trading days following the announcement of trading statements in the Chinese stock market. This finding is stronger for positive announcements in terms of the magnitude and the variance of stock returns. Our findings are in-line both with Shin's (Journal of Accounting Research, 2006) theoretical predictions and the credibility hypothesis, in which disclosure and asset returns are jointly determined and the adoption of a "sanitization strategy" in information disclosure generates more volatile returns for firms issuing good news. Further, we show that the latter effect is more pronounced for firms which are partially state-owned, suggesting that they potentially receive more government support, a finding which is in-line with the hypothesis that the incentive to suppress negative information is related to a country's legal/judicial system.
\end{abstract}

JEL classification: G14; G15; C5

Keywords: Asymmetric post-announcement drift; Voluntary trading disclosures; Disclosure strategy; State ownership; Chinese stock market

\footnotetext{
${ }^{a}$ Corresponding author. Tel.: +44 (0)1225 383883; fax: +44 (0)1225 386473. Address: School of Management, University of Bath, United Kingdom. Email addresses: x.chen@bath.ac.uk and Louisa.Chen@bankofengland.co.uk

${ }^{\mathrm{b}}$ Tel.: +44 (0)20 73319129. Address: Department of Economics, University of Greenwich, United Kingdom. Email address:

E.M.Solomon@greenwich.ac.uk

'Tel.: +44 (0)1225 386314; fax: +44 (0)1225 386473. Address: School of Management, University of Bath, United Kingdom. Email address: t.verousis@bath.ac.uk
} 
The authors would like to acknowledge the considerable comments and assistance of Eleanor Morgan, Editor of the Journal, and two anonymous referees in revising this paper. Many helpful comments on the paper were also provided by Ian Tonks, Gordon Kemp, Peter Simmons and other participants at research seminars at University of Essex and University of York, UK. 


\title{
Asymmetric post-announcement drift to good and bad news: Evidence from voluntary trading disclosures in the Chinese stock market
}

\begin{abstract}
This paper investigates the post-announcement drift (PAD) of stock returns in the Chinese stock market. We use a sample of voluntary trading disclosures to test the hypothesis that an asymmetric PAD exists in a market in which managers are more likely to suppress negative news. We show that a pattern of short-term momentum and long-term reversal in returns persists for up to 250 trading days following the announcement of trading statements in the Chinese stock market. This finding is stronger for positive announcements in terms of the magnitude and the variance of stock returns. Our findings are in-line both with Shin's (Journal of Accounting Research, 2006) theoretical predictions and the credibility hypothesis, in which disclosure and asset returns are jointly determined and the adoption of a "sanitization strategy" in information disclosure generates more volatile returns for firms issuing good news. Further, we show that the latter effect is more pronounced for firms which are partially state-owned, suggesting that they potentially receive more government support, a finding which is in-line with the hypothesis that the incentive to suppress negative information is related to a country's legal/judicial system.
\end{abstract}

JEL classification: G14; G15; C5

Keywords: Asymmetric post-announcement drift; Voluntary trading disclosures; Disclosure strategy; Market reaction; Chinese stock market 


\section{Introduction}

The main implication of the Efficient Market Hypothesis (EMH) is that security prices fully reflect all available information at any given point in time (see Samuelson, 1965; Fama, 1970 and 1991). One of the principal channels through which new information is released is via trading statement announcements (hereafter TSAs), the timing and content of which are in contrast to macroeconomic news announcements, controlled by managers of the firm. In a theoretical study, Shin (2006) generates predictions that associate voluntary disclosure in earnings announcements with disclosure risk, which seem to explain the short-term momentum and long-run stock return reversal; and further show that firms which have had a positive surprise in earnings have more volatile subsequent earnings than firms which have had a negative surprise in earnings. In this paper, we test Shin's (2006) theoretical predictions in the optimal setting of voluntary TSAs in the Chinese stock market, in which managers have a high incentive to adopt a "sanitization strategy". ${ }^{1,2} \mathrm{We}$ demonstrate that there is strong evidence in favour of the association of asymmetric post-announcement drift (hereafter, PAD) and the "sanitization strategy" hypothesis. We also demonstrate that the characteristics of the Chinese stock market affect the PAD in stock returns. In particular, the momentum and reversal pattern following a positive TSA is more pronounced for partially state-owned firms than for privately-owned firms, a finding that confirms the hypothesis that managers of partially state-owned firms are more likely to adopt a "sanitization strategy" due to greater government support. This provides further confirmation of Shin's (2006) predictions.

One of the most pervasive anomalies in stock markets is short-term investor under-reaction to news and long-term price reversal (see Shleifer, 2000). In particular, a large body of literature (see Balakrishnan, Bartov and Faurel, 2010; Ayers, Li and Yeung, 2011) has shown that, following good news, stocks outperform immediately after the announcement. However, in the long-term, stock prices are found to overreact to news, hence stocks with a long history of 
news announcements tend to exhibit low long-run average returns (see Narayanamoorthy, 2006). It is evident that the magnitude and pervasiveness of the PAD, i.e., the short-term momentum and long-term reversal in stock return, presents a sharp challenge to the EMH.

One theoretical explanation of the short-term momentum and the long-term reversal in returns is offered by Shin (2006), where asset returns and disclosure risk are jointly determined. Disclosures convey information and resolve price uncertainty; however, the constant flow of information increases price volatility. Assuming that managers adopt a "sanitization strategy", the probability that the firm will announce positive earnings in the next period follows a Poisson distribution. Hence, when the expected earnings increase, so does the volatility of the expected earnings. ${ }^{3}$ In other words, good news is expected to raise market expectations of short-term stock return volatility (i.e., in a period from one disclosure to the next) and reduce market expectations of long-term return volatility (i.e., in a period from one disclosure to the firm's terminal date). Accordingly, short-term returns increase at the expense of long-term returns. The suppression of bad news also implies that a smaller short-term flow of negative information will have fewer informative disclosures and thus a lower price volatility; therefore stock returns following good news disclosures are expected to be more volatile than those following bad news disclosures. That is, as explained by Shin (2006), the drift phenomenon and the adoption of a "sanitization strategy" are the two sides of the same coin.

The essence of Shin's (2006) argument is further related to the credibility hypothesis documented in the empirical literature (see Jennings, 1987; Hutton, Miller and Skinner, 2003; Rogers and Stocken, 2005). The credibility hypothesis postulates that managers have an incentive to embellish good news, and to suppress the disclosure of bad news. We argue that this is more likely to occur in countries with weaker legislation governing security, and a lower risk of litigation. In such an environment, managers will tend to withhold bad news as 
much as possible; conversely, investors will view good news disclosures with scepticism, and regard bad news disclosures as being more reliable. We therefore expect a smaller market overreaction following bad news disclosures.

In this study, we investigate the PAD of stock returns following firms' disclosures of positive and negative TSAs in the Chinese stock market during the period of 2002 to $2013 .{ }^{4}$ Motivated by Shin's (2006) asset pricing model and the credibility hypothesis, we intend to address the notion that PADs are associated with managers' disclosure strategy. Hence, we hypothesize that in an low-litigation risk environment (e.g., in a developing market such as Chinese stock market) where managers are more likely to adopt a "sanitization strategy" in information disclosure, PADs which follow the disclosure of good news are expected to be greater in magnitude, and more volatile, than PADs which follow the disclosure of bad news.

We show that a pattern of short-term momentum and long-term reversal in returns exists for up to 250 trading days following the announcement of trading statements in the Chinese stock market. This finding is stronger for positive announcements relative to negative ones. Positive announcement PADs, measured by buy-and-hold abnormal returns (hereafter, BHAR), are stronger than negative PADs. The PAD variance, generated by the BHAR, is more volatile after positive announcements than negative announcements. Finally, we show that short-term momentum and long-term reversal is more evident for firms which are partially state-owned than for firms which are entirely privately owned. One possible explanation is that, in a developing market where the legal system is not rigidly applied, firm managers are more likely to adopt a sanitization strategy because of the expected low risk of litigation (see Bushman, Piotroski and Smith, 2004; La Porta, Lopez-de-Silanes and Shleifer (2006). The incentive is arguably stronger for firms that are under state ownership as they potentially receive more government support and hence are more likely to utilize a "sanitization strategy" in information disclosures (see Piotroski, Wong and Zhang, 2013). 
The cross sectional regression analysis on firms' BHARs shows that state ownership significantly affects a firm's BHAR in the short-term (i.e., 3 months after the announcement). ${ }^{5}$ Further, a characteristic unique to the Chinese stock market, the float ratio (the proportion of tradable shares in a firm's capital), is also found to explain BHARs. Overall, our findings in the Chinese stock market are in-line with Shin's (2006) theoretical model and the credibility hypothesis.

We contribute to the existing PAD literature in a number of ways. First, consistent with Shin's (2006) predictions and the findings of the empirical literature (see, for example, Shleifer, 2000; Narayanamoorthy, 2006), we document a short-term momentum and longterm reversal in stock returns (i.e., PAD) following the release of trading statement announcements on the Chinese stock market. Second, we report an asymmetric momentum and reversal pattern. More specifically, the market reaction to good news is stronger and more volatile relative to bad news, a finding that further confirms Shin (2006) and the credibility hypothesis. Third, we use a more efficient proxy to capture earnings' surprises (i.e., a firm's voluntary TSA). Finally, we investigate the determinants of the PAD in the Chinese stock market and relate the PAD to market characteristics.

The rest of the paper is organized as follows. Section 2 discusses the empirical literature on the asymmetric response to good and bad news and the PAD. Section 3 presents the data and methods. Section 4 reports and discusses the results, and Section 5 concludes the paper.

\section{Literature review}

There is a large body of empirical literature on the asymmetric market reaction to good and bad news (see Kothari, Shu and Wysocki, 2009, for a summary of the related literature). 
Skinner (1994) examines earning-related voluntary disclosures on the NASDAQ and finds that directors make pre-emptive bad news disclosures. In addition, bad news disclosures generate larger stock price reactions than good news disclosures. The author argues that U.S. securities laws impose an asymmetric loss function on managers; announcements of large negative earnings surprises increase the likelihood of potentially costly stockholder lawsuits, but no such effect is associated with large positive earnings surprises. For the U.S. market, Chan (2003) reports a smaller PAD for stocks that release good public news relative to bad public news for up to 12 months after the scheduled announcement. Chen, Chiang and So (2003) show that negative news from the U.S. market causes a larger decline in stock returns compared to positive news of the same magnitude. The authors attribute this asymmetric phenomenon to the leverage effect. Kothari et al. (2009) also show evidence of an asymmetric post-announcement drift; however they attribute this to managers' deliberate delay in the disclosure of bad news. Soffer, Thiagarajan and Walther (2000) find that managers disclose bad news promptly (or early) but disclose good news gradually; hence firms with negative earnings announcements have lower excess returns in the period from just before the pre-announcement to just after the earnings announcement.

For the Chinese market, Truong (2011) finds that negative earnings surprises generate a larger drift than positive earnings surprises, conjecturing that the asymmetric PAD is caused by short sale constraints. As the paper by Truong (2011) refers to the Chinese stock market, we need to point out the differences between our study and Truong's (2011) study. First, while Truong (2011) uses the difference between the firm's realized earnings and the median of earnings forecasts as a proxy of earnings surprise, we use the firm's voluntary trading statement disclosures. Voluntary trading disclosures can exactly capture the 'surprise' element regarding firms' forthcoming profit (see the description of trading statement in the following section). Second, Truong (2011) only investigates abnormal returns that are 
associated with extreme earnings surprises (i.e., the top $20 \%$ of the distribution of the absolute value of earnings surprises in the sample). In this paper, we look at a wider spectrum of TSAs. Finally, in contrast to Truong (2011), we also investigate the PAD in the Chinese stock market and relate the PAD to the characteristics unique to the Chinese stock market, such as the percentage of state ownership and the fraction of tradable shares over the issuing firm's total shares outstanding.

\section{Data and methods}

\subsection{Data}

One of the key variables of interest in this study is the proxy for an earnings surprise. In line with the theoretical proposition of Shin (2006), we rely on voluntary disclosures to capture the 'surprise' element of a company announcement. In particular, since 2001 and in agreement with similar regulation in developed markets, the two Chinese stock exchanges Shanghai Stock Exchange and Shenzhen Stock Exchange imposed the following trading statements' rule:

Where to the knowledge of a company's directors there is a substantial change in the company's profit or in the performance of its business of Year 2001, the company must issue trading statements concerning the change within 30 workdays after the end of Year 2001. (Shanghai Stock Exchange and Shenzhen Stock Exchange, 2001)

Latterly, this rule has been extended to "quarterly trading statements". Positive and negative TSAs are released in the public domain with the uniform titles "expected profit increase statement" and "profit warning statement", respectively. Therefore, positive (negative) TSAs refer to good (bad) news. 
We collect TSA data for the Chinese stock market from Wind Financial. Our dataset covers all quarterly TSAs from August 2002 to April 2013. We apply two filters. First, if firms have two sequential TSAs and the period between the two announcement dates is less than 12 months, then both TSAs are excluded to avoid an overlap of the event windows of the two events. Second, we exclude TSAs that do not contain a full set of information in the regression analysis. The final sample contains 464 quarterly TSAs of which 99 are positive and 365 are negative; in terms of ownership structure, 302 TSAs refer to state-owned forms and 162 TSAs refer to privately-owned firms. Figure 1 presents the frequency of TSAs over the sample period. Data on the market capitalization of the firm, the percentage of the state ownership, and the float ratio $^{6}$ of the firm are extracted from each firm's annual or semiannual financial statements prior to the TSAs in question. Together with daily stock prices and the market-to-book ratio of the firm, these data are provided by Wind Financial. FTSE Xinhua A2007 daily prices are extracted from DataStream.

(INSERT Figure 1 around here)

As we will describe in the Section 3.2, we transform the market capitalization of the firm (SIZE), the percentage of the state ownership of the firm (STATE), and the float ratio of the firm $(F R)$ to the natural logarithm of their original values. Descriptive statistics of the final sample are presented in Table 1 . The average value of $M B$ on 60, 120 and 250 trading days after the TSA is $3.709,3.478$ and 3.66, respectively. As expected, the average value of SIZE, STATE and FR is relatively constant for up to 250 trading days after the TSA, which is $25.279,4.442$ and 4.605 , respectively. 
(INSERT Table 1 here)

\subsection{Methods}

We apply an event-study analysis. The timeline of the event study is described as follows: $t(0)$ is the TSA announcement day; $\mathrm{t}(-1,1)$ is the announcement period which we use to measure the instant market reaction to information release $;^{8} \mathrm{t}(2,60), \mathrm{t}(2,120)$ and $\mathrm{t}(2,250)$ refer to the post-announcement event windows. To be in line with Shin (2006), "short-term" is defined as being from one quarterly TSA date to the next (i.e., from the event day 0 to 60 ); "long-term" is defined as one quarter after the TSA date (i.e., from the event day 61 to 250). Since TSAs are assumed to have a long-term effect on stock prices, we apply a buy-and-hold abnormal return strategy to measure the impact of TSAs on stock returns (see Barber and Lyon, 1997). The BHAR of stock $i$ over the period $\left(\tau_{1}, \tau_{2}\right)$ is estimated as

$$
\operatorname{BHAR}_{i\left(\tau_{1}, \tau_{2}\right)}=\prod_{t=\tau_{1}}^{\tau_{2}}\left[1+R_{i t}\right]-\prod_{t=\tau_{1}}^{\tau_{2}}\left[1+E\left(R_{i t}\right)\right]
$$

where $R_{i t}$ is the realized daily stock return; $E\left(R_{i t}\right)$ is the FTSE Xinhua A200 market index return, e.g., a proxy of expected $R_{i t} \cdot{ }^{9} B H A R_{\left(\tau_{1}, \tau_{2}\right)}$ is presented as a percentage in the paper. The average $B H A R_{\left(\tau_{1}, \tau_{2}\right)}$ over the period $\left(\tau_{1}, \tau_{2}\right)$ across all sample event stocks, $\overline{\operatorname{BHAR}}_{\left(\tau_{1}, \tau_{2}\right)}$, is 


$$
\overline{\operatorname{BHAR}}_{\left(\tau_{1}, \tau_{2}\right)}=\frac{1}{N} \sum_{i=1}^{N} B H A R_{i\left(\tau_{1}, \tau_{2}\right)}
$$

where $N$ is the number of events. To test the null hypothesis that $\overline{B H A R}_{\left(\tau_{1}, \tau_{2}\right)}$ is significantly different from zero, the t-statistic is suggested in Brown and Warner (1980) and Campbell, Lo and Mackinlay (1997):

$$
t=\overline{\operatorname{BHAR}}_{\left(\tau_{1}, \tau_{2}\right)} / \sigma\left[B H A R_{\left(\tau_{1}, \tau_{2}\right)}\right] / \sqrt{N}
$$

where $\sigma\left[B H A R_{\left(\tau_{1}, \tau_{2}\right)}\right]$ is the standard deviation of the estimated $B H A R_{\left(\tau_{1}, \tau_{2}\right)}$ over the sample event stocks.

Further, we investigate whether the asymmetric PAD can be explained by the unique characteristics of the firm structure of Chinese listed firms. Since the Chinese stock market started trading in 1990, large state-owned enterprises have gone public through the stock market. From April 2005 to 2007, the Chinese stock market went through a further privatization reform which is referred to as the "share conversion" which aimed to reduce the non-tradable state ownership of listed firms. By the end of 2012, the state-owned shares still accounted for $9.89 \%$ of total market capitalization and the tradable shares accounted for $74 \%$ of the total market capitalization. ${ }^{10}$ We estimate the following cross-sectional regression model to analyze the potential driving forces of local market characteristics to asymmetric PADs: 


$$
\operatorname{BHAR}_{i\left(\tau_{1}, \tau_{2}\right)}=\alpha+\left(T S A_{i}, M B_{i}, \operatorname{SIZE}_{i}, \operatorname{STATE}_{i}, F R_{i}\right) \beta+\varepsilon_{i}
$$

where TSA takes the value of one for positive TSAs and zero for negative TSA; $M B$ is the market-to-book ratio; SIZE is the natural logarithm of the market capitalization of the firm; STATE is the natural logarithm of the percentage of the state ownership of the firm; $F R$ is the natural logarithm of the firm's float ratio. STATE and $F R$ are unique to Chinese stock market. Size and market-to-book ratio, i.e., $M B$ and SIZE, are well-known predictors of the crosssection of stock returns (see Fama and French, 1992 and 1993). We examine the average BHAR in three post-announcement periods: $t(2,60), t(2,120)$ and $t(2,250)$.

\section{Empirical results}

\subsection{PAD to good news vs bad news}

We report the PAD for up to one year (i.e., 250 trading days) following a TSA. In addition, we report the results for the whole TSA sample and also partition the sample into four subsamples according to the following considerations. First, in-line with the literature, we partition the sample to positive and negative trading statement surprises. Second, we expect that the state character of partially state-owned firms may have an effect on the managers' ability to withhold negative news and also on the way the market reacts to news generated by partially state-owned firms. In Table 2 we present the estimated average BHARs for the whole TSA sample and the sub-samples in the immediate announcement period $t(-1,1)$, and the short-term of $t(2,60)$ and the long-terms of $t(2,120)$ and $t(2,250)$ in the post- 
announcement periods. In total, there are 66 (236) positive (negative) TSAs for the partially state-owned firms and 33 (129) TSAs for the privately-owned firms.

(INSERT Table 2 here)

For the immediate announcement period $\mathrm{t}(-1,1)$, the average BHAR is $2.887 \%$ for positive TSAs and $-4.416 \%$ for the negative TSAs. Both figures are highly significant, implying that the market reacts with a significant sharp rise (fall) to good (bad) news in the immediate aftermath of a TSA. For positive TSAs, the average BHAR continues to rise in the short-term, i.e., the average BHAR is $7.214 \%$ at $5 \%$ significance level for the period $t(2,60)$. The BHAR becomes insignificant and is reduced to $3.682 \%$ and $-1.139 \%$ in the long-term for $\mathrm{t}(2,120)$ and $\mathrm{t}(2,250)$, respectively. This inverse U-shaped pattern for positive TSAs indicates a shortterm momentum and long-term reversal that is well-documented in the literature (see Foster, Olsen and Shelvin, 1984; Shin, 2006). For negative TSAs, the average BHAR is $0.515 \%$, $0.487 \%$ and $2.208 \%$ in the post-announcement periods of $\mathrm{t}(2,60), \mathrm{t}(2,120)$ and $\mathrm{t}(2,250)$, respectively. Although the average BHARs remain insignificant in the post-announcement periods, these results are some evidence that the market reverses quickly in the short-term.

Move on to the results of the sub-samples of partially state-owned firms and privately-held firms. Table 2 shows that, for the partially state-owned firms, the PAD exhibits a clear pattern of short-term momentum and long-term reversal. The average BHAR for positive TSAs is $3.148 \%, 6.893 \%, 0.523 \%$ and $-13.233 \%$ in the event windows of $\mathrm{t}(-1,1), \mathrm{t}(2,60), \mathrm{t}(2,120)$ and $t(2,250)$, respectively. The results are significant for the immediate announcement period $t(-$ $1,1)$, but remain insignificant for longer intervals. The average BHAR rises to its peak around one quarter after the announcement, and falls afterwards. This finding implies that, after an 
upward short-term momentum following the disclosure of good news, the market reverses in the long-term (i.e., up to one year following the TSA announcement), and even becomes negative one year following the announcement. For the negative TSAs of partially stateowned firms, the market reaction is strong and significant on the immediate announcement period $\mathrm{t}(-1,1)$ with an average BHAR of $-4.806 \%$, before it quickly rebounds and becomes close to zero for the subsequent periods. For the privately-owned firms and the immediate announcement period $\mathrm{t}(-1,1)$, the results are similar to those of the whole TSA sample and highly significant. However, for positive TSAs, the PAD continues to rise for the entire postannouncement periods, albeit significance is retained in the short-term following the TSA. In contrast, the reversal for the negative TSAs is retained for the entire post-announcement period but remains insignificant.

Further, there is a distinctive difference in the magnitude of the market reaction to good and bad news. Table 2 demonstrates that for the whole sample, the magnitude of the average BHARs of positive TSAs in the post-announcement periods are greater than those of negative ones, except for the period $\mathrm{t}(2,250)$. When looking at the sub-samples of partially stateowned firms and privately-owned firms, the magnitude of the average BHARs of positive TSAs are greater than those of negative ones in all the post-announcement periods. These findings imply that the stock market reaction to good news is stronger than bad news in the post-announcement period.

In order to visualize the patterns of PADs we described above, in Figures 2 to 4 we plot the daily average BHAR, separately for positive and negative TSAs for the event window $\mathrm{t}(-1$, 250) and also separately for the whole sample, for the sub-samples of partially state-owned firms and privately-owned firms. Figure 2 shows that, for the whole sample, the momentum of BHAR to positive news lasts for approximately 60 trading days (i.e., in the short-term), peaks at around $16 \%$ and subsequently reverses to zero approximately 190 trading days after 
the TSA. The average BHAR of negative TSAs is relatively stable at $2 \%$ for a period of approximately 100 trading days and it reverts to zero in the long-term. For partially stateowned firms, Figure 3 shows a similar momentum and reversal effect following positive TSAs, however it becomes clear that return reversal is much more pronounced compared to Figure 2 - the average BHAR becomes negative approximately one year after the TSA. The average BHAR following negative TSAs is still more stable than that following positive TSAs in the post-announcement periods. Figure 4 shows that for privately-owned firms, the momentum is sustained for a much longer period and there is an asymmetric reaction to good news and bad news - while the PAD of positive TSAs exhibits an upward drift in the year after the announcement, the PAD of negative TSAs is relatively stable and close to zero, particularly before in the first 200 post-announcement days.

(INSERT Figures 2-4 around here)

In summary, Table 2 and Figures 2 to 4 show a pronounced PAD following trading statement announcements. However, two distinctive features arise: first, the short-term momentum and long-term reversal is more pronounced for good news than for bad news; second, the effect is more pronounced for partially state-owned firms than privately-owned firms. This further confirms Shin (2006) that the asymmetric drift is more pronounced when firms are more likely to withhold bad news. Figure 2 clearly shows that in the long-term, the fall in BHARs for good news is higher than the rise in BHARs for bad news. This pattern is also reflected numerically in Table 2, in particular for partially state-owned firms.

In Table 3, we estimate the variance of the average BHAR for each TSA-specific and firmspecific group for the post-announcement periods of $t(2,60), t(2,120)$ and $t 2,250)$. We use an 
F-test to test the hypothesis that within each of the three groups (i.e., all firms, partially stateowned firms and privately-owned firms), the variance of average BHAR for positive TSAs is greater than the variance of the average BHAR for negative TSAs in the same postannouncement period. For the whole sample, Table 3 shows that the variance of negative TSAs is significantly greater than the variance of positive TSAs for all the short- and longterm post-announcement periods. Similar results are found even when we split the sample into partially state-owned firms and privately-owned firms. In particular, partially stateowned firms exhibit a higher variance relative to privately-owned firms in all the postannouncement periods. This finding implies that state-ownership might cause a more volatile PAD following the disclosure of good news than bad news in a manner similar to the one discussed in Table 2.

(INSERT Table 3 here)

Overall, our findings confirm Shin's (2006) predictions where the drift phenomenon and the adoption of a "sanitization strategy" are the two sides of the same coin. We conjecture that the above findings hold in a developing market such as the Chinese stock market, in which the legal system is not rigidly applied and the chance that stockholders may sue managers when there are large stock price declines on earnings announcement days is low (see Bushman et al., 2004; Piotroski et al., 2013; La Porta et al., 2006). Since low expected legal costs make managers more likely to adopt a sanitization strategy, we expect that the latter is particularly true for firms that are partially owned by the government, who may potentially receive more government support. We show that, under the assumption of the adoption of a "sanitization strategy" by firm managers, the PAD to TSAs exhibit short-term momentum and long-term reversal. Furthermore, the market reaction to positive TSAs is stronger than 
negative TSAs, with a greater variance of BHARs for positive TSAs relative to negative TSAs. As hypothesized, these findings are particularly true to partially state-owned firms as those firms' managers are more likely to supress bad news. Our findings are opposite and confirm the results found for the developed markets where legal costs of withholding bad news are high and a "sanitization strategy" is less likely to be pursued by managers (see Skinner, 1994; Collett, 2004; Chen et al., 2003; Kothari et al., 2009).

\subsection{Determinants of PAD}

To further investigate whether the asymmetric PAD of TSAs is caused by the unique characteristics of Chinese firms, such as the level of state ownership and the proportion of untradeable shares embedded in a firm's capital structure, we estimate the cross sectional regression of Equation (4) separately for the two groups in our sample (i.e., partially stateowned firms and privately-owned firms) and for the three post-announcement windows. The cross-sectional regressions are estimated using OLS with robust standard errors to adjust a minor violation of residuals normality. The results are presented in Table 4 .

(INSERT Table 4 here)

In the short-term (i.e., $\mathrm{t}(2,60))$, the estimated coefficients of $T S A$ are uniformly positive for both groups. In the long-term, (i.e., $\mathrm{t}(2,120)$ and $\mathrm{t}(2,250)),{ }^{11}$ the estimated TSA coefficients are still positive for privately-owned firms but are negative for partially state-owned firms. Significance is established at $5 \%$ for partially state-owned firms in $t(2,250)$ only. The result provides some evidence that, in the short-term, positive TSAs lead to a higher BHAR than negative TSAs irrespective of a firm's ownership structure; however, in the long-term, the 
market reverses for partially state-owned firms but not for privately-owned firms, in which positive TSAs disclosed by partially state-owned firms result in a lower BHAR compared to negative TSAs. The coefficient of state ownership in a firm's capital structure (STATE) has a significantly negative impact on the firm's BHAR in the short-term of $t(2,60)$ for the partially state-owned firms, but this impact becomes positive and insignificant in the longer postannouncement periods. This result (alongside the results in Table 3 and Figures 3 and 4) confirms that state ownership is associated with a more profound pattern of asymmetric PAD compared to privately-owned firms. This is due to the fact that state-owned firms' managers are more likely to employ a "sanitization strategy" taking advantage of possible government support. Crucially, the higher level of state ownership in the firm leads to lower BHAR, as indicated by the negative coefficient of STATE. As firms with higher level of state-owned shares will potentially receive more government support, this can dilute the consequences of the disclosures; the market reaction to disclosures from state-owned firms is less strong. This is also quantitatively reflected in Table 2 .

In most of the cases, the proportion of tradable shares $(F R)$ in a firm's capital structure has a significantly positive impact on the firm's BHAR during the short- and long-term for the two groups of firms. This implies that the asymmetric market reactions to good and bad news is, to some extent, caused by the unique capital structure of Chinese firms. The estimated coefficients of the control variables of market-to-book ratio $(M B)$ and firm size $(S I Z E)$ are positive and significant in most of the post-announcement periods for both firm groups. ${ }^{12}$

\section{Conclusion}

One of the most pervasive anomalies in stock markets is short-term investor under-reaction to news and long-term price reversal (see Shleifer, 2000). However, there are only a handful of studies that shed light on the asymmetric PAD to good news and bad news, and most of these 
studies find that market reaction to bad news is stronger than it is to good news. Motivated by Shin (2006), we examine the asymmetric PAD in the Chinese stock market where a sanitization strategy is more likely to be adopted by managers due to insufficient securities law and low litigation risk.

We show that the short-term momentum and long-term reversal in stock returns exists for up to 250 trading days following the quarterly announcements of trading statements in the Chinese stock market. This finding is stronger for positive announcements relative to negative ones. The magnitude and the variance of the positive announcement PADs, measured by a buy-and-hold abnormal return strategy, are stronger than negative PADs. This is particular true for firms with state-owned shareholders. By controlling for the size and market-to-book effect, the cross sectional analysis shows that state ownership can explain a firm's BHAR for up to 3 months after a TSA; the float ratio can explain a firm's BHAR for up to one year after the announcement.

We contribute to the PAD literature in a number of ways. First, consistent with Shin's (2006) predictions and the findings of the empirical literature (see, for example, Shleifer, 2000; Narayanamoorthy, 2006), we document a short-term momentum and long-term reversal in stock returns (i.e., PAD) following the release of trading statement announcements in the Chinese stock market. Second, we report an asymmetric momentum and reversal pattern. More specifically, market reaction to good news is stronger and more volatile relative to bad news, a finding that further confirms Shin (2006) and the credibility hypothesis. Third, we use a more efficient proxy to capture earnings' surprises (i.e., a firm's voluntary TSA). Finally, we investigate the determinants of the PAD in the Chinese stock market and relate the PAD to market characteristics. 
Our findings show that the asymmetric PADs between good and bad news is strongly associated with the firm's disclosure strategy. In a developing market where litigation risk is low (e.g., the Chinese stock market), managers are more likely to withhold bad news, causing the market to react more strongly to good news than to bad news. The latter is in line with the empirical literature that transparency and the incentive to suppress negative information are strongly related to a country's legal/judicial regime and political career concerns (see Bushman et al., 2003; Piotroski et al., 2011). Partially state-owned firms potentially receive more government support and thus managers are more likely to withhold bad news, and that may explain why asymmetric PADs for partially state-owned firms are more pronounced than that for privately-owned firms. Our findings are consistent with Shin's (2006) theoretical model and lend support to the credibility hypothesis that bad news is more reliable, and therefore not expected to generate strong investor under-reaction compared to good news. 


\section{References}

Ayers, B., Zhen Li, O., Yeung, E., 2011. Investor trading and the post-earningsannouncement drift. The Accounting Review 86 (2), 385-416.

Balakrishnan, K., Bartov, E., Faurel, L., 2010. Post-loss/profit announcement drift. Journal of Accounting and Economics 50 (1), 20-41.

Barber, B.M., Lyon, J.D., 1997. Detecting long-run abnormal stock returns: The empirical power and specification of test statistics. Journal of Financial Economics 43 (3), 341372.

Brown, S., Warner, J., 1980. Measuring security price performance. Journal of Financial Economics 8 (3), 205-258.

Bushman, R., Piotroski, J., Smith, A., 2004. What determines corporate transparency? Journal of Accounting Research 42 (2), 207-252.

Campbell, J.Y., Lo, A.W., Mackinlay, A.C., 1997. The econometrics of financial markets. Princeton University Press.

Chan, W.S., 2003. Stock price reaction to news and no-news: Drift and reversal after headlines. Journal of Financial Economics 70 (2), 223-260. 
Chen, C.W.S., Chiang, T.C., So, M.K.P., 2003. Asymmetrical reaction to US stock-return news: Evidence from major stock markets based on a double-threshold model. Journal of Economics and Business 55 (5-6), 487-502.

Collett, N., 2004. Reactions of the London Stock Exchange to company trading statement announcements. Journal of Business Finance and Accounting 31 (1-2), 3-35.

Fama, E., 1970. Efficient capital markets: A review of theory and empirical work. Journal of Finance 25 (2), 383-417.

Fama, E., 1991. Efficient capital markets: II. Journal of Finance 46 (5), 1575-1617.

Fama, E., French, K., 1992. The cross-section of expected stock returns. Journal of Finance $47(2), 427-465$.

Fama, E., French, K., 1993. Common risk factors in the returns on stocks and bonds. Journal of Financial Economics 33 (1), 3-56.

Foster, G., Olsen, C., Shevlin, T., 1984. Earnings releases, anomalies, and the behavior of security returns. The Accounting Review, 59 (4), 574-603.

Hutton, A., Miller, G., Skinner, D., 2003. The role of supplementary statements with management earnings forecasts. Journal of Accounting Research 41 (5), 867-890.

Jennings, R., 1987. Unsystematic security prices movements, management earnings forecasts, and revisions in consensus analyst earnings forecasts. Journal of Accounting Research $25(1), 90-110$.

Kothari, S.P., Shu, S., Wysocki, P.D., 2009. Do managers withhold bad news? Journal of Accounting Research 47 (1), 1-36. 
La Porta, R., Lopez-de-Silanes, F., Shleifer, A. 2006. What Works in Securities Laws? Journal of Finance 61 (1), 1-32.

Narayanamoorthy, G., 2006. Conservatism and cross-sectional variation in the post-earnings announcement drift. Journal of Accounting Research 44 (4), 763-89.

Piotroski, J.D., Wong, T.J., Zhang, T., 2013. Political incentives to suppress negative information: Evidence from Chinese listed firms. Working Paper. Stanford University.

Rogers, J., Stocken, P., 2005. Credibility of management forecasts. The Accounting Review $80(4), 1233-1260$.

Samuelson, P., 1965. Proof that properly anticipated prices fluctuate randomly. Industrial Management Review 6 (1), 41-49.

Shin, H.S., 2006. Disclosure risk and price drift. Journal of Accounting Research 44 (2), 351379.

Shleifer, A. 2000. Inefficient markets: An introduction to behavioral finance. Oxford, UK: Oxford University Press.

Skinner, D.J., 1994. Why firms voluntarily disclose bad news. Journal of Accounting Research 32 (1), 38-60.

Soffer, L.C., Thiagarajan, S. R., Walther, B. R., 2000. Earnings preannouncement strategies. Review of Accounting Studies 5 (1), 5-26.

Truong, C., 2011. Post-earnings announcement abnormal returns in the Chinese equity market. Journal of International Financial Markets, Institutions \& Money 21 (5), 637661. 
Table 1. Summary statistics

This table presents summary statistics of the variables in Equation (4). $M B$ refers to the market-to-book ratio, SIZE refers to the natural logarithm of the market capitalization of the issuing firm, STATE refers to the natural logarithm of the percentage of the firm's state ownership, and $F R$ refers to the natural logarithm of the fraction of the market value of tradable shares over the total market value of the firm.

\begin{tabular}{lrrrr} 
Variables & \multicolumn{1}{l}{ Mean } & Std. Dev. & \multicolumn{1}{l}{ Min } & \multicolumn{1}{l}{ Max } \\
\hline Event day t=60 & \multicolumn{5}{c}{} \\
\hline MB & 3.709 & 5.023 & -25.990 & 34.454 \\
SIZE & 21.285 & 0.942 & 19.056 & 25.756 \\
STATE & 3.384 & 1.093 & -6.502 & 4.442 \\
FR & 3.879 & 0.501 & 1.609 & 4.605 \\
\hline
\end{tabular}

Event day

$\mathrm{t}=120$

\begin{tabular}{lrrrr}
\hline$M B$ & 3.478 & 5.421 & -38.440 & 44.145 \\
SIZE & 21.259 & 0.959 & 18.854 & 25.734 \\
STATE & 3.384 & 1.093 & -6.502 & 4.442 \\
$F R$ & 3.898 & 0.511 & 1.609 & 4.605 \\
\hline
\end{tabular}

Event day

$\mathrm{t}=250$

\begin{tabular}{lrrrr}
\hline$M B$ & 3.660 & 6.144 & -37.042 & 33.390 \\
SIZE & 21.265 & 1.042 & 18.747 & 25.279 \\
STATE & 3.384 & 1.093 & -6.502 & 4.442 \\
$F R$ & 3.909 & 0.519 & 1.419 & 4.605 \\
\hline
\end{tabular}


Table 2. Average buy-and-hold abnormal returns (BHARs)

This table reports the average buy-and-hold abnormal returns (BHARs) in the on- and post-tradingstatement-announcement (TSA) periods of $(-1,1),(2,60),(2,120)$ and $(2,250)$, where the event day is defined as day 0 . The average BHAR is given by Equations (1) and (2), and is equivalent to the average of individual firm's excess stock returns (i.e., individual firm's stock return subtracted by market index return); positive TSA refers to the TSA with the title "expected profit increase statement" disclosed by individual firms; negative TSA refers to the TSA with the title "profit warning statement" disclosed by individual firms; partially state-owned firms refer to firms have both state ownership and private ownership; privately-owned firms refer to firms have private ownership only. The t-test null hypothesis: BHAR is significantly different from zero. The t-statistics appear in italics. $* * *$ and $* *$ refer to $1 \%$ and $5 \%$ significance level, respectively.

\begin{tabular}{|c|c|c|c|c|c|c|}
\hline \multirow{2}{*}{$\begin{array}{l}\text { Event windows } \\
\text { (in day) }\end{array}$} & \multicolumn{2}{|c|}{ All firms } & \multicolumn{2}{|c|}{$\begin{array}{l}\text { Partially state-owned } \\
\text { firms }\end{array}$} & \multicolumn{2}{|c|}{ Privately-owned firms } \\
\hline & $\begin{array}{l}\text { Positive } \\
\text { TSAs }\end{array}$ & $\begin{array}{l}\text { Negative } \\
\text { TSAs }\end{array}$ & $\begin{array}{l}\text { Positive } \\
\text { TSAs }\end{array}$ & $\begin{array}{l}\text { Positive } \\
\text { TSAs }\end{array}$ & $\begin{array}{l}\text { Negative } \\
\text { TSAs }\end{array}$ & $\begin{array}{l}\text { Positive } \\
\text { TSAs }\end{array}$ \\
\hline \multirow[t]{2}{*}{$(-1,1)$} & 2.887 & -4.416 & 3.148 & -4.806 & 2.363 & -3.702 \\
\hline & $6.722 * * *$ & $-18.970 * * *$ & $5.591 * * *$ & $-16.202 * * *$ & $3.769 * * *$ & $-10.101 * * *$ \\
\hline \multirow[t]{2}{*}{$(2,60)$} & 7.214 & 0.515 & 6.893 & -0.212 & 7.857 & 1.845 \\
\hline & $2.235 * *$ & 0.351 & 1.530 & -0.108 & $2.163 * *$ & 0.884 \\
\hline \multirow[t]{2}{*}{$(2,120)$} & 3.682 & -0.487 & 0.523 & -0.953 & 10 & 0.365 \\
\hline & 0.999 & -0.254 & 0.113 & -0.365 & 1.653 & 0.142 \\
\hline \multirow[t]{2}{*}{$(2,250)$} & -1.139 & 2.208 & -13.233 & -0.58 & 23.047 & 7.309 \\
\hline & -0.168 & 0.666 & $-2.036^{* *}$ & -0.145 & 1.538 & 1.246 \\
\hline No. of TSs & 99 & 365 & 66 & 236 & 33 & 129 \\
\hline
\end{tabular}


Table 3. Variances of the average BHARs

This tables reports the variances of the average buy-and-hold abnormal returns (BHARs) in the post-tradingstatement-announcement (TSA) periods of $(2,60),(2,120)$ and $(2,250)$, where the event day is defined as day 0 . The variables BAHR, positive TSA, negative TSA, partially state-owned firms and privately-owned firms are defined in Table 2. The F-test hypothesis: the variance of the average BHARs of positive TSAs is greater than that of negative TSAs. The F-statistics appear in italics. $* * *, * *$ and $*$ refer to $1 \%, 5 \%$ and $10 \%$ significance level, respectively.

\begin{tabular}{lllllll}
\hline \multirow{2}{*}{$\begin{array}{c}\text { Event } \\
\text { windows }\end{array}$} & \multicolumn{2}{c}{ All firms } & \multicolumn{2}{c}{$\begin{array}{l}\text { Partially state owned } \\
\text { firms }\end{array}$} & \multicolumn{2}{c}{ Private firms } \\
\cline { 2 - 7 } & Positive & Negative & Positive & Negative & Positive & \\
& TSs & TSs & TSs & TSs & TSs & Negative TSs \\
\hline$(2,60)$ & $\mathbf{3 . 7 5 4}$ & $\mathbf{0 . 5 9 0}$ & $\mathbf{4 . 0 7 5}$ & $\mathbf{0 . 3 2 2}$ & $\mathbf{3 . 7 2 1}$ & $\mathbf{1 . 8 5 4}$ \\
F-stat & $6.368^{* * *}$ & & $12.666^{* * *}$ & & $2.008^{* *}$ & \\
$(2,120)$ & $\mathbf{8 . 4 3 9}$ & & $\mathbf{2 3 . 4 5 7}$ & $\mathbf{0 . 7 7 4}$ & $\mathbf{7 . 4 1 3}$ & $\mathbf{2 . 0 4 7}$ \\
F-stat & $4.938^{* * *}$ & & $11.128^{* * *}$ & & $3.576^{* * *}$ & \\
$(2,250)$ & $\mathbf{8 . 4 3 9}$ & & $\mathbf{2 3 . 4 5 7}$ & $\mathbf{2 . 5 2 9}$ & $\mathbf{2 0 . 4 0 3}$ & $\mathbf{2 . 3 7 3}$ \\
F-stat & $8.439^{* * *}$ & & $23.457^{* * *}$ & & $1.663^{*}$ & \\
\hline No. of TSs & 99 & 365 & 66 & 236 & 33 & 129 \\
\hline
\end{tabular}


Table 4. Estimates of Equation (4)

This table reports the estimates of Equation (4) in the post-trading-statement-announcement (TSA) periods of $(2,60),(2,120)$ and $(2,250)$, where the event day is defined as day 0. TSA refers to the dummy variable that takes the value of one for positive TSAs and zero for negative TSAs. Variables MB, SIZE, STATE and $F R$ are defined in Table 1; the variables BHAR, positive TSA, negative TSA, partially state-owned firms and privately-owned firms are defined in Table 2. Tstatistics appear in italics. $* * *, * *$ and $*$ refer to $1 \%, 5 \%$ and $10 \%$ significance levels, respectively.

\begin{tabular}{|c|c|c|c|c|c|c|}
\hline \multirow{2}{*}{$\begin{array}{l}\text { Event windows } \\
\text { Dependent } \\
\text { variable= BHAR } \\
(\%)\end{array}$} & \multicolumn{2}{|c|}{$(2,60)$} & \multicolumn{2}{|c|}{$(2,120)$} & \multicolumn{2}{|c|}{$(2,250)$} \\
\hline & $\begin{array}{l}\text { Partially state- } \\
\text { owned firms }\end{array}$ & $\begin{array}{l}\text { Privately-owned } \\
\text { firms }\end{array}$ & $\begin{array}{c}\text { Partially state- } \\
\text { owned firms }\end{array}$ & $\begin{array}{l}\text { Privately-owned } \\
\text { firms }\end{array}$ & $\begin{array}{l}\text { Partially state- } \\
\text { owned firms }\end{array}$ & $\begin{array}{c}\text { Privately-owned } \\
\text { firms }\end{array}$ \\
\hline \multirow[t]{2}{*}{$T S A$} & 3.706 & 6.425 & -2.041 & 8.939 & -13.703 & 15.804 \\
\hline & 0.80 & 1.53 & -0.42 & 1.36 & $-1.91 * *$ & 1.09 \\
\hline \multirow[t]{2}{*}{$M B$} & 0.922 & 0.514 & 1.017 & 0.204 & 3.063 & 1.831 \\
\hline & $2.63 * * *$ & $1.63 *$ & $1.94 *$ & 0.57 & $3.78 * * *$ & $2.03 * *$ \\
\hline \multirow[t]{2}{*}{$S I Z E$} & 11.936 & 2.948 & 13.887 & 5.851 & 17.826 & 24.627 \\
\hline & $3.51 * * *$ & $1.62 *$ & $5.74 * * *$ & $2.26^{* *}$ & $5.45 * * *$ & $4.39 * * *$ \\
\hline \multirow[t]{2}{*}{ STATE } & -2.285 & - & 1.578 & - & 0.706 & - \\
\hline & $-1.66^{*}$ & - & 0.91 & - & 0.25 & - \\
\hline \multirow[t]{2}{*}{$F R$} & 8.000 & 7.057 & 22.006 & 11.014 & 28.526 & 4.503 \\
\hline & 1.61 & $2.24 * *$ & $4.14 * * *$ & $2.38 * *$ & $3.88 * * *$ & 0.33 \\
\hline \multirow[t]{2}{*}{ cont. } & -277.731 & -93.083 & -381.989 & -171.37 & -497.950 & -547.128 \\
\hline & $-4.12 * * *$ & $-2.35 * *$ & $-7.00 * * *$ & $-3.38 * * *$ & $-6.24 * * *$ & $-5.57 * * *$ \\
\hline R-squared (\%) & 18.51 & 7.47 & 20.96 & 10.56 & 27.55 & 20.87 \\
\hline No of obs. & 302 & 162 & 302 & 162 & 302 & 162 \\
\hline
\end{tabular}




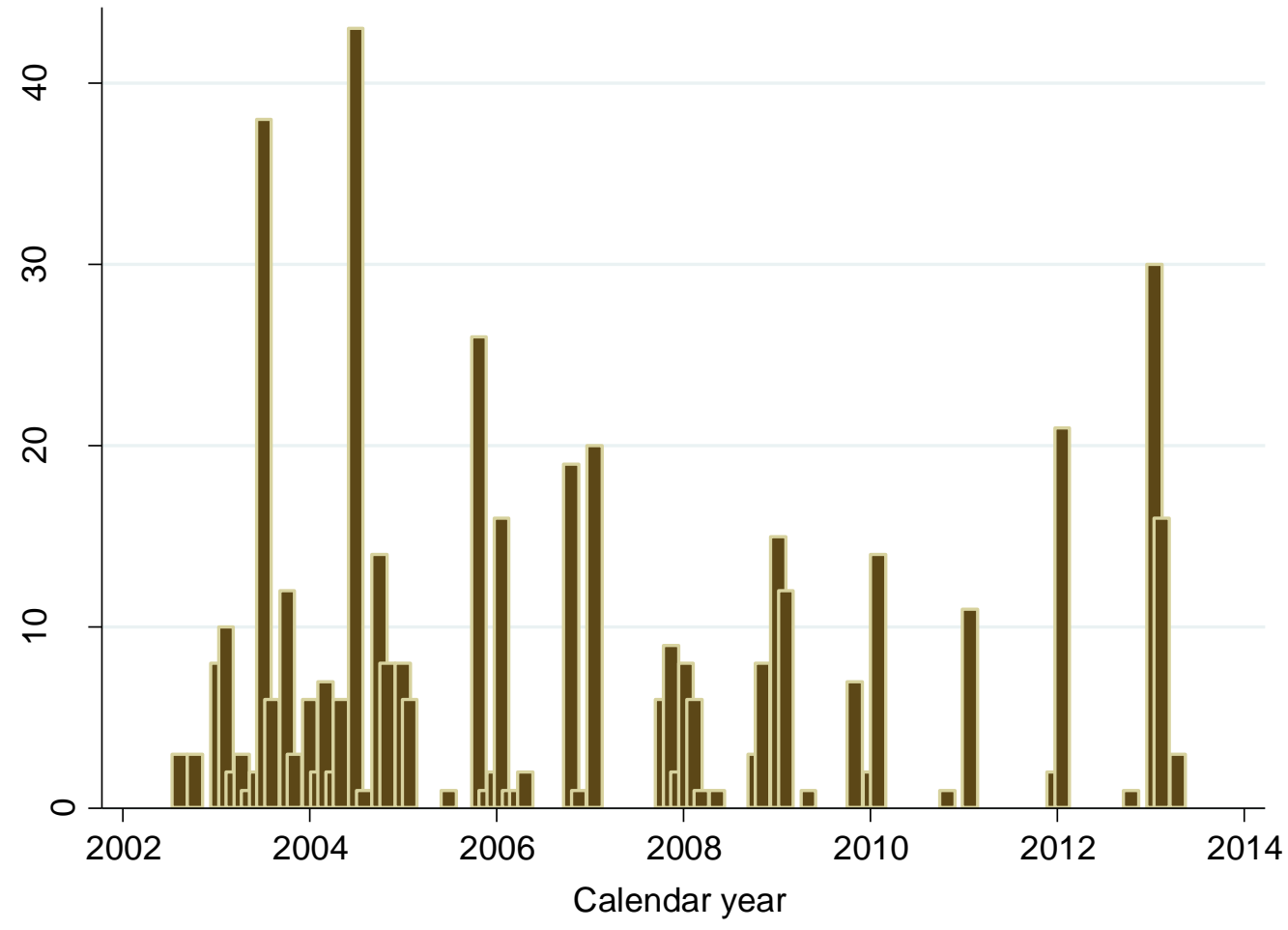

Figure 1. The frequency of the trading statement announcements (TSAs) in the sample period 20022013. 


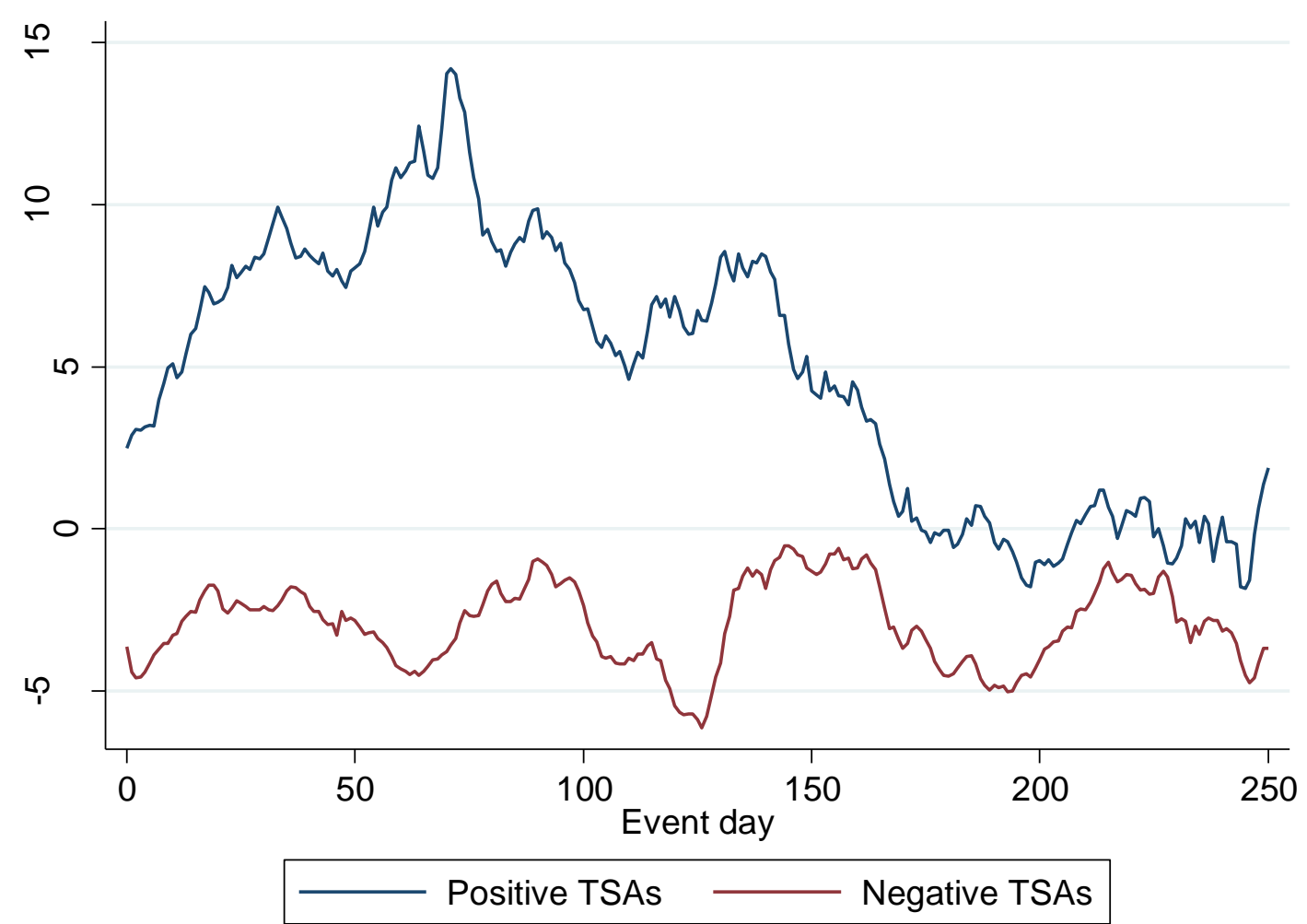

Figure 2. The average BHARs of the whole positive and negative TSAs samples in event window $(-1,250)$, where the event day is defined as day 0 . The variables BHAR, positive TSA and negative TSA are defined in Table 2. 


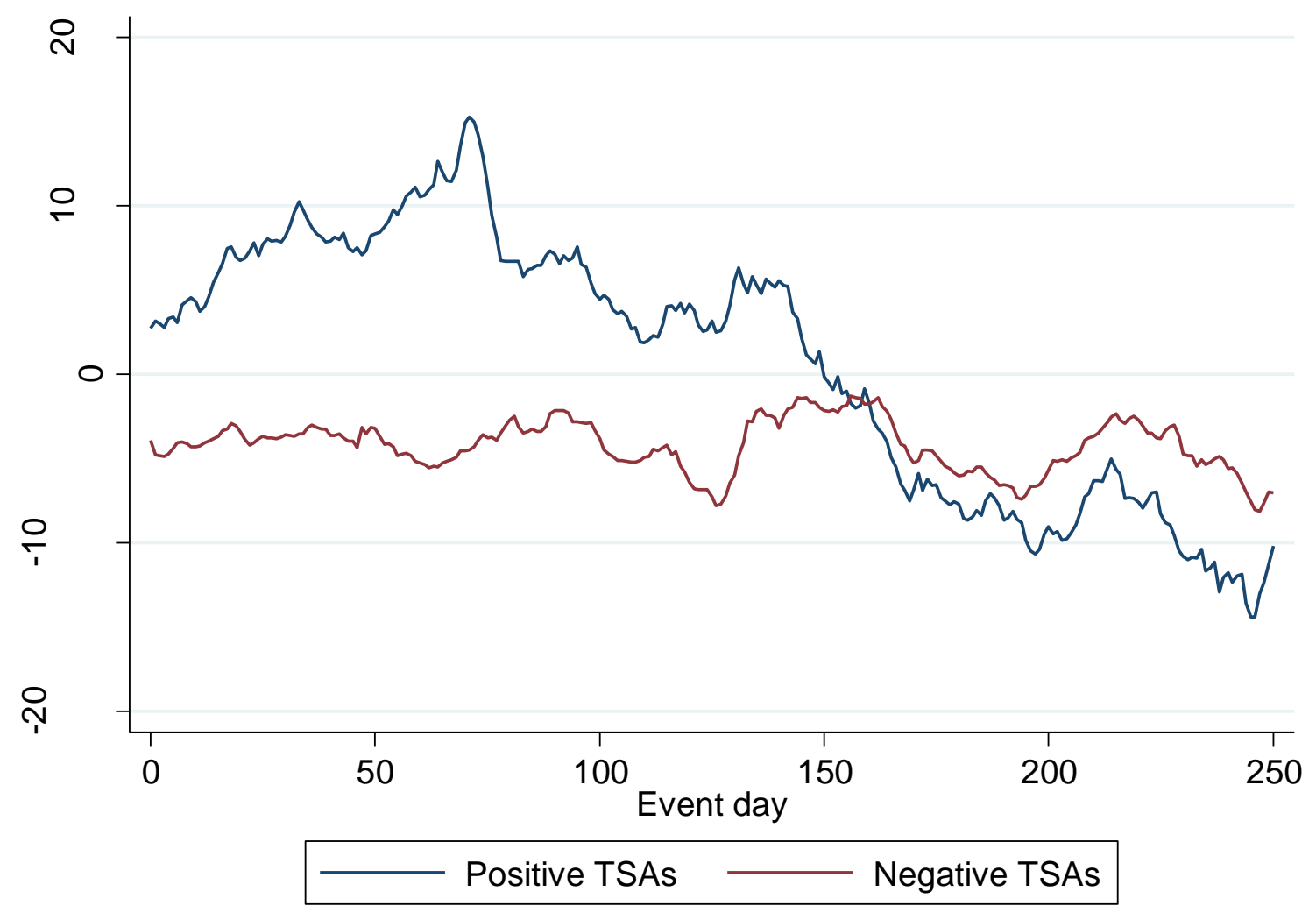

Figure 3. The average BHARs of positive and negative TSAs for partially state-owned firms in event window $(-1,250)$, where the event day is defined as day 0 . The variables BHAR, positive TSA, negative TSA and partially state-owned firms are defined in Table 2. 


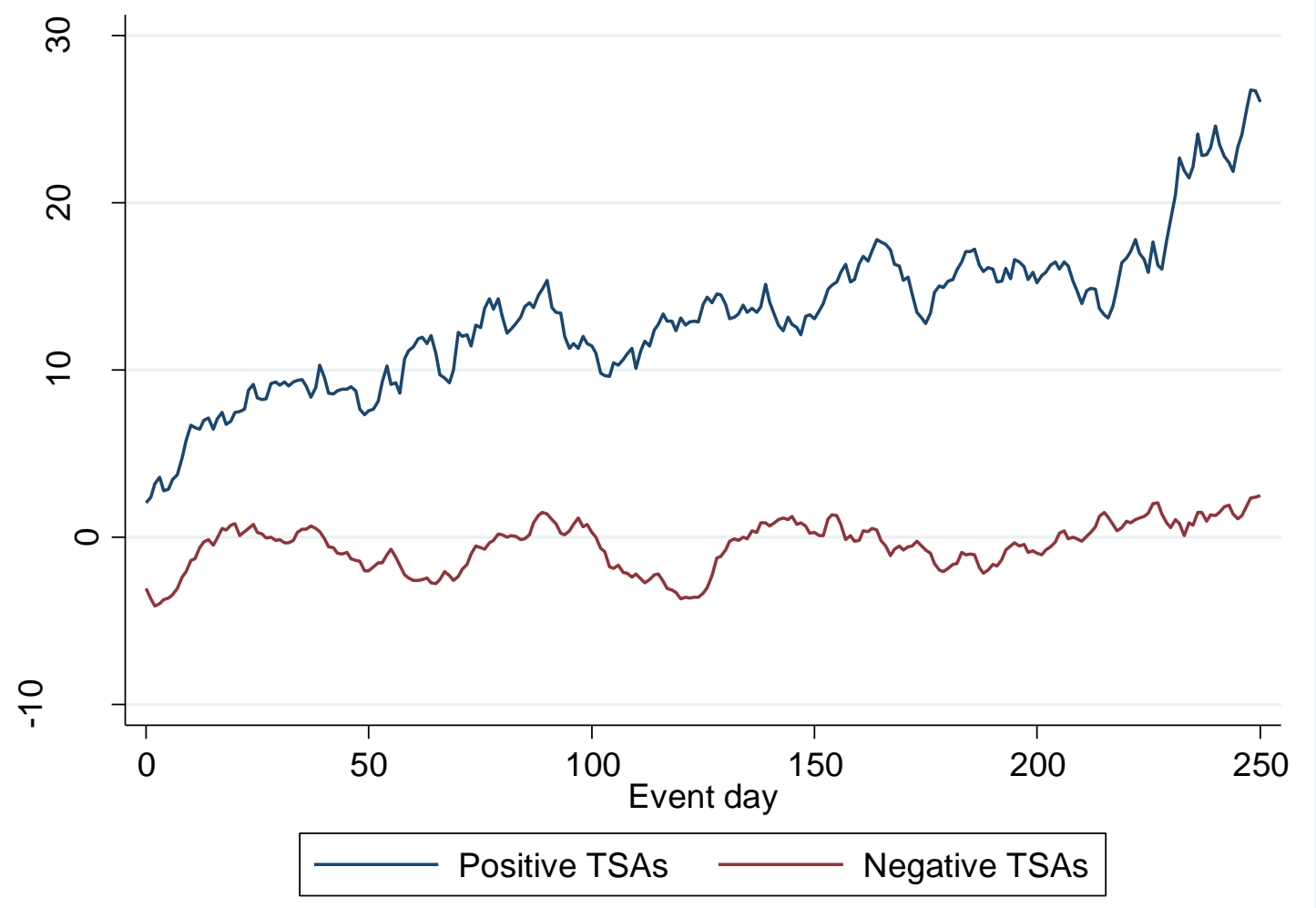

Figure 4. The average BHARs of positive and negative TSAs for privately-owned firms in event window $(-1,250)$, where the event day is defined as day 0 . The variables BHAR, positive TSA, negative TSA and privately-owned firms are defined in Table 2.

\footnotetext{
${ }^{1}$ A disclosure is "sanitized" by removing bad news and keeping good news only. This is a metaphor for the way in which managers use their discretion to present news to the market (see Shin, 2006).

${ }^{2}$ In a corporate governance context, Piotroski et al. (2013) for Chinese companies, and Bushman et al. (2004) for a number of industrial countries, demonstrate that transparency and the incentive to suppress negative information are strongly related to both a country's legal/judicial regime and to political career concerns.

${ }^{3}$ Recall that the mean of a Poisson random variable is also its variance.

${ }^{4}$ The Chinese stock market refers to both, the Shanghai Stock Exchange and the Shenzhen Stock Exchange.
} 
${ }^{5}$ In other words, the level of state ownership significantly increases the stock price (i.e., firm value) in the shortterm.

${ }^{6}$ Float ratio is the ratio between the market value of tradable shares and the total market value of the firm, where tradable shares exclude state-owned shares and legal person shares due to the fact that state-owned shares and legal person shares are untradeable in the open market. Legal person shares are those owned by domestic institutions, including non-bank financial institutions and SOEs that have at least one non-state owner.

${ }^{7}$ FTSE Xinhua A200 index is the large cap A-share index constructed out of the top 200 companies (ranked by market capitalization) in the FTSE Xinhua Index Series.

${ }^{8}$ The announcement window includes the day before and after the announcement day due to the possible information leakage before the announcement, and the fact that some TSAs are released to the public after the stock market closes on the announcement day.

9 Using stock prices, $\mathrm{P}_{i}$, and market index prices, $\mathrm{P}_{F T S E}$, Equation (1) can be expressed as $B H A R_{i\left(\tau_{1}, \tau_{2}\right)}=\frac{P_{i, \tau_{2}}}{P_{i, \tau_{1}}}-\frac{P_{F T S E, \tau_{2}}}{P_{F T S E, \tau_{1}}}$, which is equivalent to excess stock returns, i.e., stock returns less the market index returns.

${ }^{10}$ See Shanghai Stock Exchange Factbook 2013 and Shenzhen Stock Exchange Factbook 2013.

${ }^{11}$ We drop two outliers in the regression for the subsample of partially state-owned firms on event window $(2,250)$ in which the regression residual is greater than 350 , and one outlier in the regression for the subsample of privately-owned firms on event window $(2,250)$ in which the regression residual is greater than 400 .

${ }^{12}$ Following a suggestion made by a referee, we have also estimated a model of Equation (4) involving the interaction terms between TSA and the other independent variables for the group of partially state-owned firms the group of privately-owned firms. The results show that the estimated coefficients of the interaction terms are in general insignificant, while the estimated coefficients of TSA are significant for partially state-owned firms in the long-term. This implies that good news has a different intercept to bad news, but has similar slopes of $M B$, SIZE, STATE and FR as bad news. To conserve space, we do not report this table (available upon request). 